\title{
ОБ’ЄДНАННЯ ГАЛИЦЬКОЇ ТА НАДДНІПРЯНСЬКОЇ АРМІЙ ВЛІТКУ 1919 року
}

У статті висвітлюеться період утворення військової коаліції між арміями УНР і ЗУНР. Розглянута спільна боротьба українських армій за незалежність молодої держави влітку 1919 року. Проаналізовано якісний і кількісний стан армій в результаті їх об’єднання.

Ключові слова: Українська Галицька Армія, ЗУНР, Наддніпрянська Армія, Начальна Команда, військова коаліція, офензива.

Актуальність теми. Важливими завданнями сучасної воєнно-історичної науки $є$ проведення аналізу i узагальнення набутого досвіду у минулих війнах. На сучасному етапі розвитку української державності залишається актуальним активізація досліджень національно-політичних процесів минулого. Одним 3 історичних прикладів усвідомлення українством соборницьких ідей $є$ об’єднання Галицької і Наддніпрянської Армій влітку 1919 р.

Історіограббічний та джерелознавчий огляд. Проаналізувавши стан дослідження проблеми, слід відзначити, що історіографія Української революції має потужний пласт воєнно-історичних та мемуарноаналітичних праць вітчизняних i діаспорних авторів. Певний внесок в їі розробку здійснили і зарубіжні автори. Першими істориками Української революцї̈, утворення УНР і ЗУНР та їх збройної боротьби за незалежність i соборність були безпосередні учасники тих подій. Голова Центральної Ради М. Грушевський підсумував перший етап державотворчих процесів у Наддніпрянщині у своїй праці «На порозі нової України» [1]. Творча спадщина С. Петлюри пронизана ідеями самостійності і соборності

Скорич Лілія Василівна, кандидат історичних наук, доцент кафедри гуманітарних наук, Національна академія сухопутних військ імені гетьмана Петра Сагайдачного, м. Львів.

(C) Скорич Л.В., 2017 
України, відтворенням маловідомих широкому загалу суспільства сторінок 3 історії визвольних змагань. Незважаючи на звинувачення у бік Петлюри з приводу визнання окупації Польщею Східної Галичини, яке сталося 3 тактичних міркувань заради військового союзу 3 Ю. Пілсудським для подальшої спільної боротьби 3 більшовиками за визволення України, він завжди був соборником, з повагою ставився до галичан та військовополітичного союзу з ЗУНР i схвалював об'єднання Галицької Армії з Армією УНР та їх спільну боротьбу [2].

Серед історичної літератури значне місце займають спогади воєначальників Наддніпрянської та Галицької Армій, вивчення яких сприяють глибокому розумінню проблеми. Відзначимо “Спогади командарма» генералполковника Михайла Омеляновича-Павленка, колишнього командувача Галицької (грудень 1918 червень 1919 рр.), згодом Армії УНР [3].

Суттевий внесок у розробку проблеми зробив підполковник Василь Прохода, його спогади Л. Шанковський назвав «добрим конспектом українського війська» [4]. Визначний історіографр Л. Шанковський у процесі досліджень на перше місце ставив науковоісторичні праці відомих воєначальників: О. Удовиченка, М. Капустянського, Р. Дашкевича, М. Безручка та інших, які у своїх працях торкалися складних процесів української революції та висвітлювали проблеми військово-політичного та дипломатичного співробітництва УНР і ЗУНР, зокрема, процес об'єднання Галицької Армії з Наддніпрянською та спільні бойові операції [5-7].

Виклад основного матеріалу. Помітною сторінкою в історії Збройних Сил України, прикладом реалізації ідей соборності було об'єднання у липні 1919 р. українських армій УНР і ЗУНР та їх спільна боротьба проти військ більшовицької Росії за незалежність молодої держави. Ці історичні події стали наслідком проголошення 22 січня 1919 р. у Киеві Акта Злуки століттями роз'єднаних гілок українського народу, які постійно прагнули до соборності.

Військова коаліція утворилася у складний період для обох держав. Армія УНР вела напружені бойові дії проти 
військ радянського Українського фрронту, які зайняли майже всю Наддніпрянщину і столицю Київ. Водночас Галицька армія від листопадових 1918 р. боїв у обороні Львова протистояла широкомасштабній агресії 3 боку Польщі, яку активно підтримувала Антанта. Витиснута поляками й румунами у трикутник на півдні Тернопільщини, вона знайшла сили для могутнього удару. На чолі 3 новим командувачем генералом Олександром Грековим Галицька армія 8 червня 1919 р. перейшла у наступ по всьому фрронту. Операція, яка увійшла в історію як Чортківська офензива, на першому етапі досягла вражаючих результатів. Корпуси О. Микитки i М. Тарнавського розгромили відбірні частини польського війська, визволили Тернопіль, Золочів, Броди й стрімко наближалися до недавньої столиці ЗУНР - м. Львова [8].

Поразка змусила Ю. Пілсудського 24 червня прибути в Східну Галичину й особисто очолити війська фрронту. Наступного дня він отримав телеграму з Парижа про те, що Найвища Рада Антанти дозволила Польщі окупувати територію Східної Галичини до Збруча, для чого використати частини прибулої з Франції армії генерала Ю. Галлера. Лише галлерівська 6-та дивізія фрранцузького генерала Шампо де Сосі мала 4500 багнетів, 110 шабель, 103 кулемети й 48 гармат. За даними учасника тих подій польського генерала В. Гуперта, Ю. Пілсудський зосередив для контрнаступу угруповання, яке нараховувало 38,6 тис. багнетів, 2,1 тис. шабель, 797 кулеметів і 207 гармат. Сили Галицької армії значно поступалися полякам. Вона мала у ті дні 24,4 тис. багнетів, 400 шабель, 376 кулеметів і 144 гармати [9].

Коли 28 червня війська Пілсудського перейшли у загальний наступ на фрронті від Бродів до Галича, Галицькі частини не витримали потужного натиску й 3 боями відійшли на схід. На початку липня 1919 р. поляки призупинили наступ, i українському війську вдалося закріпитися й утримувати південь Тернопільщини. Уряд ЗУНР і Начальна Команда армії осіли у Бучачі, а згодом у Заліщиках. Таким чином, Чортківська наступальна

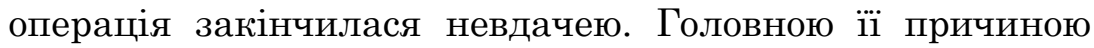


був брак зброї та набоїв, унаслідок чого генералові Грекову не вдалося використати 90 тисяч добровольців, яких відпустили по домівках. Додамо, згідно 3 польськими даними, Галицька армія зазнала суттевих втрат: потрапили у полон близько 10 тисяч вояків i захоплено ворогом 50 гармат і 129 кулеметів [10].

$\mathrm{He}$ заглиблюючись у докладний аналіз тактикостратегічних причин невдачі Чортківської операції, відзначимо одну із важливих, на якій наголошував Л. Шанковський: «Червень 1919 року перейде в нашу воєнну історію, як місяць, в якому братні українські армії, віддалені від себе не більш 50 км, вели дві офрензивні операції проти двох різних ворожих сил. Армія УНР вела свою Проскурівську операцію, яка початково теж мала великі успіхи ... Таким чином дві одночасні українські офензиви, які мали великі початкові успіхи, покінчалися обидві поразкою». Автор вважав, що спільні дії обох українських армій на тому чи іншому фронті безумовно були успішними. Щоправда, Л. Шанковський вважав що слід було зосередити спільні зусилля на основному, тобто більшовищькому фронті. Тим більше що у дні Чортківської операції 16 червня місія УНР генерала Дельвіга у Львові підписала договір про перемир'я [4].

Зауважимо, що вказаний договір брав до уваги лише тимчасове припинення бойових дій між військами Польщі й ЗУНР і не був державно-правовим актом. Щоправда, він залишав за галичанами територію у межиріччі Серета i Збруча, а також Тернопіль. Угода з поляками була вигідна насамперед С. Петлюрі, який відверто намагався використати Галицьку армію у боротьбі з більшовиками. Більше того, вже у травні наполегливо вмовляв керівництво ЗУНР припинити бойові дії на польському фрронті й перекинути Галицьку армію проти більшовиків. Отримавши негативну відповідь, Головний Отаман віддав наказ Начальній Команді, але вона його не виконала, посилаючись на позицію президента республіки. Можливо, певні дивіденди, у випадку порозуміння з Польщею, заробляв і уряд Петрушевича: посилював позицію ЗУНР на Паризькій мирній конференції, оскільки Антанта щиро 
прагнула припинити українсько-польську війну. Відтак, можливо, Найвища Рада не прийняла б фратального для галичан рішення про дозвіл польському війську окупувати Східну Галичину. Крім того, залишалися шанси забезпечити армію 3 допомогою прихильних Чехословаччини й Угорщини, а головне - союзної УНР [11].

Проте заключена наддніпрянською делегацією Дельвіга угода сталася у час найбільшого успіху Галицької армії в Чортківській операції, й віддавати полякам зайняті землі майже до Львова для галичан було, безперечно, принизливим. Є. Петрушевич i командарм О.Греков сподівалися силами двох новосформованих корпусів посилити південне крило армії, а саме 3-й корпус А. Кравса. Відтак, стало цілком можливим досягнути Карпатських перевалів, тобто чеського кордону, отримати зосереджені в Лавочному ешелони із закупленим військовим майном і набоями й поповнити армію вояками, інтернованими в Чехословаччині, й полоненими в Італії. Згодом завдати полякам ударів на Львів з напрямків Тернополя і Стрия. Начальна Команда повідомила поляків, що не визнає справедливими умови перемир'я, а головне демаркаційну лінію Дельвіга. Поляки спритно використали у Парижі фракт зриву перемир'я галичанами, а для Вищої Ради це стало вагомим аргументом для прийняття рішення 25 червня 1919 р. [10].

«Галичани прагнули за всяку ціну нарешті здобути свою столицю Львів і тільки там замиритися 3 поляками, зауважував генерал Армї УНР М. Капустянський. - Під гіпнозом ціеї великої мети, i окрилені блискучими успіхами своєї Народньої армї, галицькі військові та політичні керівники недооцінили ні сил ворога, ні значення підтримки, яку йому давала Франція... Тільки на самому героїзмі й запалі неможливо базуватися. Здається, треба було використати слушний момент і досягти хоч тимчасового замирення (перепочинку) з поляками» [6].

На початку липня 1919 р. уряд ЗУНР осів у Заліщиках і спільно з військовиками розмірковував щодо подальших перспектив i шляхів їх реалізації. Варіантів було 
декілька. Один із них запропонував радянський уряд України Х. Раковського, який намагався скористатися важким становищем ЗУНР. Наближений до Є. Петрушевича Осип Назарук свідчив про те, що Харків пропонував військовий союз проти Польщі й Румунії, надати необхідне озброєння й амуніцію Галицькій армії та об’єднати їі з Червоною. Він заявляв про невтручання у внутрішні справи Галичини після її звільнення. Водночас висувалися дві умови: повністю розірвати відносини 3 Петлюрою й відкликати 3 Армї̈ УНР корпус Січових Стрільців Є.Коновальця. «Ви іншого виходу не маєте, наголошував командувач Українським фронтом В. Антонов-Овсієнко, - тільки або піти з нами або героїчно загинути» [12].

За своєю ініціативою, без узгодження з Петрушевичем генерал Греков вислав делегацію у складі сотників В. Гадзінського, С. Магаляса й Г. Давида, яка зустрілася у Бердичеві 3 наркомом військових справ радянської УкраїниМ. Подвойським. Під час переговорів радянський нарком заявив, що червоні «не тільки можуть нам доставити усяку кількість амуніції і зброї, але готов навіть дати поміч своїми збройними силами, якщо ми погодимося на їх умови». Однією 3 головних передумов була видача Головного Отамана С. Петлюри i призначення до галицьких військових частин радянських зв'язкових старшин. Обіцялося після розпуску корпусу Січових Стрільців Є. Коновальця передати його галицьких вояків Начальній Команді.

Слід відзначити, що серед галицьких військовиків i урядовців певна частина підтримували діалог 3 радянською Україною, зокрема колишній голова уряду С. Голубович, отамани I. Сіяк і О. Букшований. «Серед національного табору Галичини, навіть серед урядових верств ЗУНР, - визнавала пізніше урядова газета «Український прапор», - були такі, котрі во ім'я ідеї національної едності готові були піти на союз 3 більшовиками, аби тільки відбити Галичину і Західноукраїнські землі від Польщі і інших окупантів». Але С. Петрушевич все ще орієнтувався на Антанту, вірив у 
справедливе вирішення галицької проблеми на Паризькій мирній конференщії, куди надіслав досвідчених дипломатів М. Лозинського, В. Панейка та військового міністра Д. Вітовського. Вірив також у декларації Вудро Вільсона й Ллойд Джорджа щодо права націй на самовизначення. Навіть після того, як 11 липня надійшло рішення Найвищої Ради про дозвіл Польщі окупувати Східну Галичину, вважав, що це тимчасова помилка Антанти, яку можна виправити. Водночас він не сподівався на те, що більшовищька Росія не втримається, відтак, все більше схилявся до пропозицій Петлюри, який часто навідувався до Заліщик і просив якнайшвидше об'єднати армії [8].

Але в декого 3 галицьких воєначальників були інші думки. На одній 3 нарад за участю Є. Петрушевича, генералів О. Грекова, М. Омеляновича-Павленка, M. Тарнавського виконуючий обов'язки військового міністра полковник В. Курманович виклав, на його погляд, найперспективніший план, який дозволяв продовжувати збройну боротьбу за Галичину. Згідно 3 цим планом Галицькій армії пропонувалося відступити в Карпати й отримати підкріплення i допомогу 3 Чехословаччини, де знаходилася інтернована чотиритисячна 1-ша Гірська бригада та ешелони військового майна в Лавочному. Через Відень, Братиславу планували перекинути 20-40 тис. галицьких військовиків 3 італійських таборів військовополонених. Звільняючи коридор між поляками й більшовиками, можна було досягнути розширення фрронту бойових дій між польською і радянською арміями, що ослаблювало б Польщу. Але цей план не схвалили насамперед Є. Петрушевич i M. Омелянович-Павленко, які під впливом заходів Петлюри домоглися рішення залишити Галичину й відступити за Збруч [2].

Варто зауважити, що відносини між Петлюрою i Петрушевичем не були безхмарними. Лідер галичан мав низку претензій до керівництва УНР. Тому з 9 липня представники уряду й Армії УНР, зокрема С. Петлюра та полковник М. Капустянський, кожного дня прибували в 
Заліщики на переговори. Лише 14 липня, коли поляки відновили бойові дії, військово-політичний провід ЗУНР прийняв нелегке рішення: відійти за Збруч. Причому Петрушевич висунув вимоги, які згодом були виконані: припинити радянофрільські спроби скорегувати зовнішньополітичний курс УНР і шукати порозуміння з Антантою; усунути сощіалістичний кабінет міністрів Мартоса; скасувати в уряді УНР міністерство для Галичини на чолі 3 С. Вітиком; надати матеріально-технічну допомогу армії. Відтак, 15 липня Начальна Команда віддала наказ військам про загальний відступ за Збруч [13].

Ще перед цим Начальна Команда Галицької армії надіслала С. Петлюрі телеграму: «Під сильним напором польських сил, за браком амуніщї й інших матеріялів, Галицька армія буде примушена перейти Збруч». С. Петлюра був надзвичайно задоволений: до УНР переходила сорокатисячна, загартована в боях 3 поляками, цілком боєздатна армія, за допомогою якої він сподівався виправити своє майже безнадійне становище на більшовицькому фрронті, а найголовніше - повернути Київ. У відповіді С. Петлюра давав цілковиту згоду на перехід Збруча. "Українська Наддніпрянська армія та ї̈ Головна Команда приймає Галицьку Українську армію, як братню, й усім їй допоможе, що в їі силах». У наказі по армії Головний Отаман 3 піднесенням писав: «На допомогу нам прийшли брати-галичани. Вони залишили свої оселі, відходячи під переважною силою ворога; але прийшли на наш терен як то належить дисциплінованій армії й свідомій у правоті свого діла і своїх змагань». Наміри щодо її використання проявилися ще до переходу Збруча. Від імені Головного Отамана Штаб Дієвої армії призначав для галичан район - на північ від Кам'янцяПодільського впритул до більшовицького фрронту у напрямку на Проскурів [13].

Відтак, упродовж 16-17 липня перейшли Збруч уряд ЗУНР на чолі 3 диктатором Є. Петрушевичем, численні групи співробітників державних установ, партійні структури, представники інтелігенції, близько 80 священиків Греко-католицької церкви - здебільшого 
польових духівників частин УГА. Організованими колонами відходили на схід полки, бригади, корпуси Галицької армії. Відступ забезпечувала 1-ша бригада Українських Січових Стрільців отамана О. Букшованого. Всього перейшло Збруч близько 100 тисяч осіб [14].

3 перших днів перебування Галицької армії за Збручем щодо ㄲï використання виявилися чималі розбіжності як між С. Петлюрою й Є. Петрушевичем, так і командуванням армій. Ще на початку липня Головний Отаман домігся усунення 3 посади командувача армї генерала О. Грекова. Над ним нависла загроза репресій 3 боку Петлюри. Внаслідок чого він був змушений емігрувати в Румунію, а згодом залишився у Відні. Усунувши О. Грекова, Головний Отаман і командування Армії УНР намагалися повністю підпорядкувати собі Галицьку армію. Але Є. Петрушевич і М. Тарнавський категорично відкинули ці наміри й зберегли Начальну Команду, самостійність своїх збройних сил, а також їх структуру та організаційні засади. Вони вважали свою армію кращою за Наддніпрянську, а досвід українськопольської війни підтвердив їі високі бойові якості. На думку М. Капустянського, «Галицька армія являла собою боєздатну регулярну армію з не зовсім відповідним, мало досвідченим командним складом; в ній панував лад, карність і добре було організоване запілля; на військове забезпечення Галицька армія була бідна. 3 національного боку це була одноманітна маса, 3 піднесеним національним почуттям» (підкр. автора) [6].

Після переходу за Збруч Галицька армія складалася 3 трьох корпусів (ще два формувалися), чотирнадцяти бригад, Етапу (запасні частини) та інших інженернотехнічних, медико-санітарних, ветеринарних, тилових фрормацій. За підрахунками В. Вериги, вона нараховувала 85 тис. старшин і стрільців, 3 них 47,7 тис. бойового складу. Крім того, вона мала 550 скорострілів, 160 гармат та 20 літаків [4].

Для виразного визначення ï внеску у подальшу збройну боротьбу за визволення України, а також ї характерних рис розглянемо стан Армії УНР на середину липня 1919 р. 
Кількісно i якісно Наддніпрянська армія суттево поступалася червоним. Армія УНР складалася з чотирьох груп: Січових Стрільців полковника Є. Коновальця, Запорізької - полковника В. Сальського, Волинської полковника В. Петріва i Повстанської - отамана Ю. Тютюнника та двох окремих дивізій - 3-ї Залізної полковника О. Удовиченка і Запорізької Січі - отамана Ю. Божка. Загалом до них входило 11 дивізій, але вони були недоукомплектованими, малочисельними. Якщо радянська дивізія згідно з штатом мала 28 тис. бійців, щоправда, фрактично у 12-й армії - 10-15 тисяч, то українські в середньому близько двох тисяч, зокрема Запорізька група, що складалася 3 трьох дивізій, нараховувала всього 3000 багнетів і шабель. Отже, армія УНР у середині липня мала загалом 15 тис. багнетів, близько 530 кулеметів і 170 гармат. Генерал О. Удовиченко визначив кількісний стан армї до 14-15 тисяч вояків бойового складу, 350-380 кулеметів і до 100 гармат. Разом із запіллям харчового складу вона нараховувалося близько 30 тис. козаків і старшин [7].

Аналізуючи якісний стан Наддніпрянської армї̈, слід відзначити, що їі рядовий склад - козацтво, який мав добрий вишкіл і фрронтовий досвід служби в російській армії, в ході світової війни відзначався дисципліною, наполегливістю при виконанні бойових завдань, презирством до смерті, в часи визвольних змагань втратив чимало позитивних рис. Головною причиною була політизація армії, а виборність командирів (отаманів), яку привносили повстанські частини, призвела до падіння дисципліни і твердого армійського усталеного порядку, 3 випадками брутального ставлення до населення.

Негативну роль також відігравала кадрова політика уряду УНР i, що найважливіше, самого Військового міністерства. При наявності в Україні за Гетьманату більше 300 генералів і кількох сотень офріцерів Генерального штабу, внаслідок недовіри до них використовувалися за призначенням лише одиниці. Чимало досвідчених генералів, які добровільно зголосилися на службу в Армію УНР, не були задіяні на 
командних посадах. Зокрема, колишній профресор академії Генштабу, командувач 8-ї армії в роки світової війни генерал-поручник М. Юнаків служив канщеляристом у міністерстві разом з колишнім начальником Генштабу при гетьмані П. Скоропадському генерал-поручником О. Галкиним. Талановиті воєначальники генералпоручники С. Дельвіг і В. Зелінський були задіяні в дипломатичних місіях, а колишній командир корпусу генерал-поручник П. Ярошевич командував двохтисячною Північною дивізією [15].

Підсумовуючи аналіз стану Наддніпрянської армії, слід погодитися 3 висновками М. Капустянського, що їі основу складали регулярні боєздатні корпуси січовиків i запоріжців, особовий склад яких виявив високу національну свідомість і відданість українській справі. Водночас помітну частину армї складали повстанські партизанські фрормування, яким бракувало належної дисципліни внаслідок, за висловом М. Капустянського, «принесення політики в армію. Різні партії провадили у війську агітацію, набуваючи собі прихильників, нерозбираючих в засобах i не дбаючи про боєздатність армії». Саме вони спровоковували антидержавні виступи отаманів Оскілка, Волоха, Божка та інших, що підривало міцність військ. Проте, наголошував генерал, у липні 1919 р. українське військо було «майже регулярною армією 3 деякими особливостями, викликаними революцією i національним рухом. Вона мала різноманітний старшинський склад із здоровим бойовим осередком, прекрасний козачий елемент, слабеньку карність... Бойова здібність, за умов рухливого большевицького фрронту, і завзятість - загалом високі». Порівнюючи Галицьку i Наддніпрянську армї̈, можна зробити висновок, що в умовах маневреної війни, битися, як писав Капустянський, «на всі чотири сторони світу», наддніпрянці переважали галичан. Проте їх об’єднання створювало «грізну, непереможну Українську збройну силу» [6].

Висновки. Таким чином, в результаті об'єднання українських армій УНР і ЗУНР суттево змінилося 
стратегічне становище в Україні на користь національновизвольних сил. 3 приходом Галицької армії вони зміцніли як чисельно, так i організаційно. За своєю структурою це була регулярна армія європейського стандарту, що позитивно відбилося на загальному стані українського війська. Відтак, стало можливим здійснити перше i головне завдання - визволити Україну 3-під більшовицької окупації.

1. Грушевський $М$. На порозі нової України: Гадки $\mathrm{i}$ мрії / М. Грушевський. - К.: Наукова Думка. 1991. - $128 \mathrm{c}$.

2. Петлюра С. Статті / С. Петлюра. - Київ, 1993. $340 \mathrm{c}$.

3. Омелянович-Павленко М. Спомини командарма / М. Омелянович-Павленко. - К.: Видавничий дім «Темпора». - 2007. - 459 с.

4. ШанковськийЛ. Українська галицька Армія / Л. Шанковський. - Львів: Вид-во «Наукове товариство імені Шевченка». - 1999. - 396 с.

5. Дашкевич $Я$. Західно-Українська Народна Республіка: негативний досвід / Я. Дашкевич // Україна: культурна спадщина, державність. Випуск 6. - Львів, 2000. - С. 355-360.

6. Капустянський $M$. Похід Українських Армій на Київ-Одесу в 1919 році. Є. Маланюк - Уривки зі спогадів. Документи та матеріали / М. Капустянський, Є. Маланюк. - Київ, 2004. - 280 с.

7. Удовиченко О. Україна у війні за державність. Історія організації бойових дій Українських Збройних Сил 1917-1921 / О. Удовиченко. - К.: Вид-во «Україна», 1995. - 176 с.

8. Литвин В.M. Українсько-польська війна 1918-1919 pр. / В.М. Литвин. - Львів, 1998. - 468 с.

9. Hupert W. Walki o Lwow (od 1 listopada 1918 do 1 maja 1919 roku). - Warszawa, 1993. - $263 \mathrm{~s}$.

10. Hupert W. Zajecie Malopolski Wschodniej I Wolynia w roku 1919 / W. Hupert. - Lwow; Warszawa, 1928. $107 \mathrm{~s}$.

11. Литвин В.M. Військова еліта Галичини / В.М. Литвин, К. Науменко. - Львів, 2004. - 373 с.

12. Назарук O. Рік на Великій Україні: Спомини 3 української революції [Електронний ресурс]. Відень, 1920 - 342 с. - Режим доступу: http://diasporiana.org.ua/memuari/372-nazaruk-o-rikna-velikiy-ukrayini/. 
13. Микитка O. Денник Начальної Команди Української Галицької Армії / О. Микитка. - НьюЙорк: Червона калина, 1974. - 343 с.

14. Центральний державний архів вищих органів влади та управління України. Ф. 2188. Начальна команда Галицької Армії Оп. 2. Спр. 57, арк. 29.

15. Колянчук $O$. Генералітет українських визвольних змагань / О. Колянчук, М. Литвин, К. Науменко. Львів, 1995. - 288 с.

Надійшла 07.02.2017 p.

Рецензент: О.Й. Дем'янюк, доктор історичних наук, професор, проректор, Луцький інститут розвитку людини університету «Україна», м. Луцьк

\section{Скорыч Л.В. \\ ОБЪЕДИНЕНИЕ ГАЛИЦКОЙ И НАДДНЕПРОВСКОЙ АРМИЙ ЛЕТОМ 1919 года}

В статье освещается период создания военной коалиции между армиями УНР и ЗУНР. Рассмотрена совместная борьба украинских армий за независимость молодого государства летом 1919 года. Проанализировано количественное и качественное состояние армий в результате их объединения.

Ключевые слова: Украинская Галицкая Армия, ЗУНР, Надднепровская Армия, Начальная Команда, военная коалиция, офензива.

\section{Skorych L.}

THE UNIFICATION OF THE GALICIAN ARMY AND THE UKRAINIAN NATIONAL ARMY IN SUMMER 1919

The period of the formation of the military coalition between the UNA and the West Ukrainian People's Republic's army is highlighted in the article. The Ukrainian armies' common struggle for independence of the new country in summer 1919 is considered. The qualitative and quantitative state of the armies as a result of their unification is analyzed.

Keywords: Ukrainian Galician Army, ZUNR (WUPR), Ukrainian National Army, the Head Team, military coalition, offensive. 